\title{
ПОНЯТІЙНО-КАТЕГОРІЙНИЙ АНАЛІЗ СУТНІСНОГО РОЗУМІННЯ ДИДАКТИЧНОЇ ІНТЕНСИФІКАЦЇ̈ НАВЧАЛЬНОЇ ДІЯЛЬНОСТІ СТУДЕНТІВ
}

Малихіна С. В. Понятійно-категорійний аналіз сутнісного розуміння дидактичної інтенсифікації навчальної діяльності студентів.

У статті висвітлено основні аспекти понятійно-категорійного аналізу сутнісного розуміння дидактичної інтенсифікації навчальної діяльності студентів, узагальнено підходи до визначення базисних понять і категорій. Авторське понятійно-категорійне розуміння дидактичної інтенсифікації навчальної діяльності студентів грунтується на організаційно-педагогічних, праксеологічних та цільових або аналітикопрогностичних підставах.

Ключові слова: дидактична інтенсифікація, навчальна діяльність студентів, понятійно-категорійний аналіз, організаційно-педагогічні підстави, праксеологічні підстави, цільові або аналітико-прогностичні підстави.

Малыхина С. В. Понятийно-категориальный анализ сущностного понимания дидактической интенсификации учебной деятельности студентов.

В статье освещены основные аспекты понятийно-категориального анализа сущностного понимания дидактической интенсификации учебной деятельности студентов, обобщены подходы к определению базисных понятий и категорий. Авторское понятийно-категориальное понимание дидактической интенсификации учебной деятельности студентов основывается на организационно-педагогических, праксеологических и целевых или аналитико-прогностических основах.

Ключевые слова: дидактическая интенсификация, учебная деятельность студентов, понятийно-категориальный анализ, организационно-педагогические основы, праксеологические основы, целевые или аналитико-прогностические основы.

Malykhina S. V. Conceptual and categorical analysis of the essential understanding the didactic intensification of students' educational activities.

The article covers the main aspects of conceptual and categorical analysis of essential understanding the didactic intensification of students' educational activities. The author summarizes approaches towards defining basic concepts and categories. The author's conceptual and categorical understanding the didactic intensification of students' educational activities relies on organizational and pedagogical, praxeological and objective or analytical and prognostic reasons.

Key words: didactic intensification, students' educational activities, conceptual and categorial analysis, organizational and pedagogical grounds, praxeological grounds, objective or analytical and prognostic grounds.

На грунті аналізу філософської, психологічної й педагогічної літератури спробуємо висвітлити основні положення стосовно здійснення понятійнокатегорійного аналізу сутнісного розуміння дидактичної інтенсифікації навчальної діяльності студентів.

Мистецтво освіти значною мірою детерміноване розумінням суті навчальновиховного процесу, визначеністю стрижневих понять і категорій. Відома фраза Конфуція про те, що будь-яка людська спільнота зекономила б собі багато часу й 
уникнула б багатьох конфліктів, коли б люди відразу домовились, що вони мають на увазі, використовуючи те чи інше означення-слово, - у науці набуває імперативного характеру. У педагогіці дуже часто зустрічаються неоднозначні потрактування понять, тож спробуємо визначитися 3 понятійно-категорійними характеристиками дидактичної інтенсифікації.

Точність тривалий час вважалася основною вимогою формулювання дидактичних понять. Однак у постнекласичній науці ситуація змінюється: прийшло усвідомлення, що одним із засобів зробити поняття більш відповідними складній, динамічній, часто невизначеній педагогічній реальності є перехід від чітких до менш чітких понять та формулювань. Спроби створення сучасної та однозначної «мови дидактики» не мають успіху: з'ясувалося, що чим більшу точність має певне визначення, тим менш повно описується за його допомогою педагогічне явище (предмет) і навпаки. Необхідність розгляду таких понять 3 «розмитим» набором ознак, що мають більшу ступінь свободи свого використання, криється не стільки в недостатній проникливості людського розуму, скільки в складності педагогічних явищ, відсутності жорстких меж та чітко окреслених класів і категорій, у постійній мінливості: той, хто постійно націлений на проведення чітких розмежувальних ліній, постійно ризикує опинитися у штучному, ним створеному світові, що має дуже мало спільного $з$ динамічним, сповненим віддінків та переходів реальним світом [7], - на сторінках свого навчального посібника застерігає А. Івін. 3 іншого боку, сучасний український дидакт Г. Атанов на сторінках монографії «Відродження дидактики запорука розвитку вищої школи» небезпідставно стверджує: «... особливістю педагогічних визначень $\epsilon$ їх багатослівність, засміченість епітетами ... Вживання епітетів там, де цього не вимагається ... перетворюється на банальність, і це накладає відбиток на всю педагогіку» [2, с. 4]. Тож зійдемося на тій точці зору, що спроможність наукової теорії адекватно відобразити сутність явищ i процесів, глибина їі висновків значною мірою залежить від зрілості й досконалості наукових понять, якими вона оперує, а на рівні окремих досліджень - досконалості понятійного апарату.

Виходячи 3 цього, мета роботи полягає у висвітленні основних аспектів понятійно-категорійного аналізу сутнісного розуміння дидактичної інтенсифікації навчальної діяльності студентів та узагальненні підходів до визначення базисних понять і категорій.

Ураховуючи сказане вище, власне розуміння дидактичної інтенсифікації навчальної діяльності студентів вищої школи ми подаємо крізь призму зіставлення та аналізу розбіжностей, наявних в основних та похідних визначеннях.

Як правило, вітчизняні й зарубіжні науковці послуговуються категорією «інтенсифікація навчання», яка $є$ висхідною щодо явища інтенсифікації навчальної діяльності. Відомо, що розв'язання проблеми інтенсифікації навчальної діяльності студентів безпосередньо пов'язане 3 оновленням способів роботи 3 теоретичним i практичним знанням у ході фахової підготовки. Епістемологія, яка вивчає різні форми існування й ретрансляції знання (В. Лекторський, Г. Щедровицький, Ф. Михайлов та інші), виявляє й аналізує ті епістемологічні способи діяльності, які формуються сьогодні в реальному секторі вищої освіти. Науковці послуговуються іiі розробками для філософсько-теоретичного обгрунтування необхідності дослідження феномена інтенсифікації навчальної діяльності студентів.

Керуючись епістемологічними настановами, власне понятійно-категорійне розуміння дидактичної інтенсифікації навчальної діяльності здійснюємо на організаційно-педагогічних, праксеологічних та цільових або аналітико- 
прогностичних підставах.

У педагогіці вищої школи накопичено достатній фонд, який дозволяє визначити дидактичну інтенсифікацію як дидактичну категорію на організаційно-педагогічних niдcmaвax, залучаючи дані сучасної педагогіки та психології. Матеріал для такого визначення знаходимо в роботах, присвячених вивченню організаційних форм навчальної діяльності в середовищі вищої освіти (Я. Болюбаш, О. Дубасенюк, В. Свдокимов, В. Краєвський, І. Кобиляцький, В. Котов, І. Прокопенко, М. Фіцула), удосконаленню методів та прийомів навчання у вищій школі (А. Алексюк, М. Свтух, Б. Коротяєв, О. Мороз).

У педагогічній літературі інтенсифікація навчання розглядається як один із шляхів підсилення, збільшення результативності навчальної праці та якості навчальної роботи [10, с. 93]. Дослідники, що вивчають явище інтенсифікації на організаційно-педагогічних засадах, виокремлюють такі їі параметри:

1) збільшення обсягу й швидкості засвоєння навчального матеріалу;

2) кількість та варіативність прийомів навчання (часто - механічне збільшення кількості вправ);

3) насиченість спілкування та дидактичної взаємодії.

Зокрема, А. Кузьмінський зазначає, що інтенсифікація навчання передбачає досягнення бажаних результатів за рахунок якісних чинників, тобто шляхом напруження, більш ефективного використання розумових можливостей особистості ... ефективніше використання можливостей і тих, хто навчає, і тих, хто навчається, найперша передумова інтенсифікації навчального процесу [8].

Дослідник процесів інтенсифікації навчальної діяльності А. Аюрзанайн свого часу (80-і роки минулого століття) писав про розуміння цього феномена як зростання напруги педагогічних процесів, пришвидшення темпів їх розвитку, які призводять до прагнення людини (суб'єкта навчального процесу) отримати найвищі результати в навчанні, можливо - у більш короткий термін [3].

Поряд 3 цим, учасники наукових дискусій, чиї погляди детерміновані організаційно-педагогічними підставами, не враховують достатньою мірою результатів логіко-методологічних досліджень проблем наукового пізнання (Кун, Лакатос, Поппер, Фейерабенд), які мають безпосереднє відношення до проблем інтенсифікації навчальної діяльності студентів вищої школи, тісний взаємозв'язок між предметним та особистісно-рефлексивним рівнями навчальної діяльності студентів. Предметний рівень інтенсифікації навчальної діяльності утворюють процеси отримання та розвитку знань за допомогою певних пізнавальних засобів та дій. Використовуючи як означення термін «предметний», маємо на увазі те значення, яке цей термін має в сучасній методології науки (у якості предметів виступають процеси, властивості, відношення). Рефлексивний рівень інтенсифікації- знання про те, як досліджувати предмет.

Елементи інтенсифікації навчальної діяльності на організаційно-педагогічних засадах знаходимо у педагогічних теоріях навчання шляхом уведення укрупнених дидактичних одиниць (П. Ерднієв), технології змістового узагальнення I. Прокопенка та В. Свдокимова, яка є адаптацією до освітніх реалій вищої школи ідей В. Давидова, навчання на високому рівні складності у пришвидшеному темпі (Л. Занков), формування навчальної діяльності (В. Рєпкін), навчання 3 комп'ютерним та мультимедійним супроводом (І. Підласий, Є. Машбиць та інші).

Тож виходячи 3 організаційно-педагогічних підстав, можемо визначити дидактичну інтенсифікацію навчальної діяльності студентів у розумінні збільщення обсягу та прискорення швидкості опанування навчального матеріалу 
за рахунок ефективного розкриття та використання можсливостей тих, хто навчається, $і$ тих, хто навчає, на грунті активації індивідуально-особистісного потенціалу суб'єктів навчального процесу та доборі оптимальних методів $i$ прийомів навчальної взаємодї.

Праксеологічні підстави спрямовують вектор дослідницького пошуку у сферу аналізу забезпечення ефективності навчальної діяльності, практики викладання та навчання у вищій школі. 3 позицій праксеологічного підходу не можуть окремо існувати знання й уміння. Людина засвоює певні види діяльності, отримуючи й переробляючи відповідну інформацію, що описує способи й прийоми діяльності, властивості об'єктів, ознаки й механізми явищ, і «факт засвоєння проявляється в умінні здійснювати діяльність» [2, с. 24]. При цьому діяльність може функціонувати в різноманітних формах: мовленнєвій, матеріальній (предметній) або розумовій, але завжди залишається однією й тією ж діяльністю, у якій можна розмежувати орієнтовну та виконавчу частини. Орієнтовна частина діяльності- це й $є$ власне знання, які виявляються у формі розумової дії, а вміння - виконавча частина діяльності, яка виявляється в мовленнєвій або матеріальній (мануальній) формі, визначають В. Беспалько та Ю. Татур [2, с. 24]. Тож у праксеології знання, уміння й навички - це одна й та ж діяльність, що здійснюється в різних формах. Тому неможливо «знати» й «не вміти» і навпаки. Емпіричні уявлення про те, що можуть існувати знання без умінь грунтується на помилковому судженні, коли діяльність уже автоматизована у мовній формі, та ще не освоєна в матеріальній, можливе й зворотне явище, однак в обох випадках «знання» й «уміння» складають нерозривну єдність.

Передача теоретичного й емпіричного знання в ході фахової підготовки передбачає спеціальні практики (освітні, комунікаційні та ін.), філософське осмислення цих практик та педагогічного опису, нових прочитань, педагогічноепістемологічних потрактувань способів улаштування теоретичного й емпіричного знання, способів роботи з ним (Н. Громико [3]), у тому числі - способів інтенсифікації цієї роботи. Ця проблема також ускладнюється тією обставиною, що на думку сучасних філософів (Т. Кун) транслювати теоретичне знання (у тому числі - під час фахової підготовки у вищому закладі освіти) об'єктивно неможливо - носії наукової інформації (підручники, посібники, електронні носії) нерідко викривляють справжню картину розвитку знання, представляють розвиток науки як лінійний процес, у той час як він здійснюється шляхом наукових революцій (Т. Кун [9]). Трансляція знань спрямовується на передавання накопичених результатів, у той час як розвиток науки пов'язаний з розв'язанням невирішених раніше проблем.

Суттєво збагачують та коректують наукові уявлення про сутність дидактичної інтенсифікації навчальної діяльності студентів дослідження, пов'язані з вивченням шляхів забезпечення якості навчання у вищій школі (С. Архангельський, I. Підкасистий, О. Соколенко), готовності студентів до професійної діяльності, шляхів вироблення необхідних професійних умінь i навичок (Т. Ільїна, С. Щербина), самостійної пізнавальної діяльності студентів (Д. Вількеєв, О. Нільсон, Т. Шамова).

Один 3 перших дидактів вищої школи с. Архангельський розглядає інтенсифікацію навчального процесу як «підвищення якості навчання при одночасному зниженні часових затрат за рахунок використання інтенсифікаційних засобів, форм i методів навчання» [1, с. 213]. Він зазначає, що ефективність викладання, учіння та навчального матеріалу й є сутність інтенсифікації.

Резерви інтенсифікації в самій навчальній діяльності відкриває П. Підкасистий: ці резерви учений пов'язує зі співвідношенням науки та навчального предмета, удосконаленням структури змісту підготовки спеціаліста високої кваліфікації та 
взаємодією репродуктивних, пояснювально-ілюстративних i творчих процесів у структурі учіння як специфічному виді пізнавальної діяльності людини. Учений наголошує на тому, що процеси інтенсифікації повинні стосуватися як репродуктивних, так i творчих типів навчальної діяльності. Визначено, що репродуктивний (пояснювально-ілюстративний) тип характеризується такими особливостями: викладач повідомляє студентам певну сукупність знань, пояснює сутність явищ, процесів, законів, правил та ін. 3 використанням ілюстративного матеріалу (у сучасному розумінні - слайдів, презентацій, навчальних фільмів тощо); студенти мають свідомо засвоїти пропоновану частину знань і відтворити іiі на рівні глибокого розуміння, застосувати знання на практиці в різноманітних видах навчальної діяльності [8, с. 184]. Цей тип навчальної діяльності певною мірою сприяв встановленню раціональних підходів до оволодіння певною сумою усталених знань, розвитку логічного мислення, оперативної пам'яті студентів та інших пізнавальних процесів. Проте він дещо гальмує самостійну пізнавальну, дослідницьку діяльність, гальмує оволодіння студентами методами самостійного пізнання.

Наукова школа 3. Курлянд трактує інтенсифікацію навчального процесу як дію, спрямовану на покращення традиційного навчального процесу, на більш досконалу його реалізацію за рахунок модернізації, модифікації, раціоналізації. У свою чергу, модернізацію вчені розглядають як дію, спрямовану на зміни відповідно до сучасних вимог та смаків. Модифікацію розглядають як дію, спрямовану на видозміну існуючого предмета чи явища, не торкаючись його сутності. Раціоналізацію розглядають як організацію доцільної діяльності, спрямовану на вдосконалення, покращення, раціональні дії, тобто дії, які спираються на розум і логіку.

Т. Ільїна убачає інтенсифікацію навчального процесу в міцному засвоєнні строго відібраного кола професійно необхідних знань та виробленні відповідних умінь і навичок за оптимально припустимий термін. Досягнення високої якості викладання вона пов'язувала 3 ретельним відбором навчального матеріалу та використанням активних методів навчання, які сприяють виробленню в студентів тих знань, які можуть мати у майбутньому практичну цінність.

Керуючись праксеологічними настановами, О. Соколенко розробляє технологію інтенсифікації навчальної діяльності: дослідниця вказує, що під інтенсифікацією навчальної діяльності варто розуміти передачу великого обсягу навчальної інформації при незмінній інтенсифікації навчання без зниження вимог до якості знань. Узагальнюючи зарубіжний досвід та досвід здійснення інтенсифікаційної діяльності педагогами навчальних закладів нового типу (ліцеїв, гімназій, коледжів), учена виокремлює чинники інтенсифікації навчальної діяльності: підвищення доцільності навчання, підсилення мотивації учіння, підвищення нормативної ємкості змісту освіти, використання активних форм і методів навчання, темпу навчальних дій, розвиток навичок навчальної праці, використання інтенсифікації та новітніх технічних засобів.

Виходячи 3 праксеологічних підстав, можна визначити дидактичну інтенсифікацію навчальної діяльності студентів як систему заходів, спрямованих на значне підвицення якості навчання за рахунок відбору й удосконалення змісту навчальної інформації, оптимального співвідночення пояснювальноілюстративних і досліднцько-творчих типів навчання, а також використання його активних форм іметодів при збереженні визначеного часового терміну.

Дидактична інтенсифікація навчальної діяльності студентів має цільовий характер, який визначається постановкою тих чи інших пізнавальних завдань. Розглянемо більш детально визначення інтенсифікації навчальної діяльності, що 
здійснюється на иільових аналітико-прогностичних підставах.

Висхідними для досліджень інтенсифікації навчальної діяльності на цільовій аналітико-прогностичній підставі $\epsilon$ ідеї персоналізації та розвитку особистості студента в навчальній діяльності (К. Абульханова-Славська, Б. Ананьєв, Л. Буєва, М. Каган, А. Ковальов, О. Леонтьєв, А. Маркова, В. Мясищев, В. Тугарінов); дослідження про інтегральні інтенсифікаційні якості особистості: суб'єктність, індивідуальність, спілкування та ставлення (О. Бодальов, І. Зимня, Б. Ломов, В. Мерлін, В. Мясищев, Б. Теплов). 3 програмно-цільовим підходом пов'язував інтенсифікацію навчальної діяльності В. Сластьонін: ця інтенсифікація, на його думку, забезпечується єдністю всіх сторін навчання, у підкоренні процесу навчання кінцевому результату, формуванні всебічно підготовленої, соціально активної особистості майбутнього спеціаліста. Тому інтенсифікація навчальної діяльності розглядалася під кутом зору пошуків та створення методів, прийомів, способів та засобів навчання, які дозволяють підвищити ефективність навчально-виховного процесу, причому не за рахунок напруги викладача та студентів у процесі навчальної праці, а за рахунок інтенсифікації навчальної діяльності більш легкою, приємною, i, водночас, результативною. Ця позиція збігається з поглядами західноєвропейських та американських дослідників, які намагаються інтенсифікувати діяльність за рахунок підсилення внутрішніх мотивів, активізації внутрішніх психологічних можливостей суб'єктів діяльності, створення відповідних умов, активації механізмів переключення тощо. Дж. Брунер, зокрема, підкреслює: «... реально пізнання завжди включене у практичну діяльність людини, тісно пов'язане 3 його потребами i мотивами, вирізняється вибірковістю, спрямованістю у майбутнє ... Прийняття рішення, пізнавальні стратегії, евристика - ось поняття, які повною мірою відбивають специфіку людського мислення» [6, с. 116].

Як перспективний напрям підвищення якості професійної підготовки студентів, систему технологічних прийомів, які дозволяють задіяти резервні можливості особистості того, хто навчається, і забезпечити результативність процесу навчання та економію навчального часу розглядає інтенсифікацію навчальної діяльності Н. Солодихіна. Є. Бондаревська зауважує, що в сучасних умовах термін інтенсифікація змикається 3 явищем «випереджувальної освіти»: «деякі дослідники пов'язують цей термін з переорієнтацією змісту діючої освіти на задоволення потреб виробництва, що розвивається, це, по суті, передбачає відому, таку, що вже реалізується в сучасній освіті адаптаційну стратегію ... Інші вбачають у такій освіті зв'язок 3 наукою, експериментальним впровадженням нових наукових ідей, концепцій, методів у вишівське навчання ... ; треті визначають як освіту просунуту, що здійснюється за поглибленими програмами підвищеної складності; четверті бачать призначення такої освіти в розвитку творчих здібностей, компетентностей та вмінь ... студентів «працювати 3 майбутнім»: проектувати, моделювати, конструювати нові середовища й технології, способи розв'язання глобальних і регіональних проблем, будувати й перевіряти варіативні гіпотези перетворення життя» [5, с. 8].

Виходячи 3 цільових аналітико-прогностичних підстав, дидактична інтенсифікація навчальної діяльності студентів- єдність новітніх та традиційних форм, прийомів, методів $і$ засобів, щцо дозволяє суттево підвищити якість навчально-виховного процесу за рахунок розкриття внутрішнього потенціалу суб'єктів навчальної діяльності, активізації внутрішніх психологічних механізмів студентів.

Узагальнюючи накопичений у педагогіці та помежових гуманітарнофілософських дисциплінах досвід, можемо стверджувати, що дидактична 
інтенсифікація - це складне діалектичне явище, яке: 1) виявляє специфічний потенціал навчально-виховного процесу вищої школи; 2) визначає місце і роль навчальної діяльності студента у багатобічному процесі його соціалізації, складовою частиною якої є фахове становлення; 3) активує методи, засоби, критерії необхідності та достатності навчальної діяльності; 4) зумовлює інтенсифікаційні принципи навчальної діяльності, перетворюючи їх на технологічні правила й рекомендації.

Уважаємо, що дидактична інтенсифікація є своєрідним ключем для зміцнення фундаментальності вищої освіти - можливості отримати знання та здобути компетенції й компетентності, які дозволяють людині після завершення навчання у вищому навчальному закладі професійно орієнтуватися в нових наукових напрямах та новітніх реаліях фахової діяльності, сприяє формуванню професійного мислення, чітких уявлень про місце й роль набутої професії в системі загальнолюдських знань та практики, допомагає виробленню цілісних уявлень на суспільство й людину в контексті міждисциплінарного діалогу. Дидактична інтенсифікація як комплексне явище забезпечує тісний взаємозв'язок фундаментальної й власне предметнопрофесійної складових фахової підготовки майбутніх спеціалістів, здатна підсилити фахове спрямування загальнотеоретичних і профільних дисциплін, озброїти студента новими професійно значимими уміннями й навичками пізнавального й практичного характеру.

Провідні положення концепції дидактичної інтенсифікації зводяться до взаємозв'язку як власне інтенсифікації навчального процесу, так і інтенсифікації психолого-педагогічних механізмів, що зумовлюють їі функціонування й розвиток.

Цей взаємозв'язок втілюється у положення про:

- взаємозумовленість інтенсифікації навчальної діяльності та інтенсифікації особистісних структур процесу учіння студента, пришвидшення процесів індивідуально-суб'єктивного пізнання;

- варіативність та видозміну стрижневих формотворчих засобів дидактичної інтенсифікації: джерел, методів і засобів формування змісту навчального матеріалу, методів структурування цього змісту (В. Краєвський та I. Лернер підкреслювали, що саме єдність змістового та процесуального компонентів у навчальній діяльності диктує необхідність уведення певних завдань із засвоєння навчальної інформації із заздалегідь заданою якістю);

- створення відповідного дидактичного середовища як цілісного системного утворення, яке визначається накопиченими знаннями, уміннями, навичками, пізнавально-культурним потенціалом суб'єктів навчальної діяльності, формами та методами аудиторних та позааудиторних різновидів навчальної роботи.

Отже, порівняння та узагальнення напрацювань провідних науковців на основі виокремлення трьох підстав у зіставленні з власними теоретичними міркуваннями дозволяє визначити дидактичну інтенсифікацію навчальної діяльності студентів вищих навчальних закладів як комплексний інтегративний феномен, щчо дозволяе повною мірою реалізувати загальні й часткові завдання фахової підготовки студента за допомогою оптимальних умов $і$ засобів при максимально ефективному використанні наявних ресурсів навчального процесу (часу, актуального матеріально-технічного й дидактико-методичного забезпечення, професіоналізму викладачів) та уможливлює досягнення кожним студентом кінцевої професійно зумовленої мети навчання у ВНЗ.

\section{Література}

1. Архангельский С. И. Учебный процесс в высшей школе, его закономерные основы и методы: [учеб-метод пособ.] / Сергей Иванович Архангельский. - М. : 
Высшая школа, 1980. - 368 с. 2. Атанов Г. А. Возрождение дидиактики - залог развития высшей школы / Геннадий Алексеевич Атанов.- Донецк : ДОУ, 2003.180 c. 3. Аюрзанайн А. А. Организация профессионально-направленной самостоятельной работы студентов в условиях интенсификации учебной деятельности: автореф. дис. на соискание учёной степени канд. пед. наук / А. А. Аюрзанайн. - M., $\quad$ 1987. 4. Беспалько В. П. Системно-методическое обеспечение учебно-воспитательного процесса подготовки специалистов / В. П. Беспалько, Ю. Г. Татур. - М. : Высшая школа, 1989. - 141 с.

5. Бондаревская Е. В. Методологические проблемы проектирования педагогического образования университетского типа / Е. В. Бондаревская // Славянская педагогическая культура. - 2011. - № 10. - С. 3-11. 6. Брунер Дж. Культура образования / Джером Брунер. - М. : Просвещение, 2006. - 223 с. 7. Ивин А. А. Логика : [учеб. пособ. для студентов вузов] / Александр Архипович Ивин.- М. : ООО «Издательство Оникс» : ООО «Издательство «Мир и Образование», 2008. - 336 с. 8. Кузьмінський А. І. Педагогіка вищої школи : [навч. посіб.] / Анатолій Іванович Кузьмінський. - К. : Знання, 2005. - 486 с. 9. Кун Т. Структура научных революций / Томас Кун. - Б. : БГК им. И. А. Бодуэна де Куртенэ, 1998. - 296 с. 10. Лингводидактический энциклопедический словарь / А. Н. Щукин. - М. : Астрель : Хранитель, 2007. - 746 с.

\section{ТЕХНОЛОГӤЇ НАВЧАННЯ СТУДЕНТІВ ІЗ ВИКОРИСТАННЯМ МІЖПРЕДМЕТНИХ ЗВ'ЯЗКІВ}

Недашковський Ю. В., Кучма О. І. Технології навчання студентів із використанням міжпредметних зв'язків.

У статті розкрито деякі аспекти підготовки вчителів трудового навчання в частині використання міжпредметних зв'язків і комп'ютерних технологій. Доведено, що запропонована методика засвідчує високі показники рівня зацікавленості студентів і доцільність використання сюжетів міжпредметних зв'язків.

Ключові слова: комп'ютерні технології, електротехнічні дисципліни, міжпредметні знання, технології навчання.

Недашковский Ю. В., Кучма А. И. Технологии обучения студентов использованием межпредметных связей.

В статье раскрыты некоторые аспекты подготовки учителей трудового обучения в части использования межпредметных связей и компьютерных технологий. Доказано, что предложенная методика подтверждает высокие показатели уровня заинтересованности студентов и целесообразность использования сюжетов межпредметных связей.

Ключевые слова: компьютерные технологии, електротехнические дисциплины, межпредметные знания, технологии обучения.

Nedashkovsky Y. V., Kuchma A. I. Teaching technologies through intersubject ties.

The article gives some aspects of preparing handicraft teachers with regard to using intersubject ties and computer technologies.

Key words: computer technologies, electrotechnical disciplines, intersubject knowledge, teaching technologies. 